\title{
Peranan Kecerdasan Emosional terhadap Penyesuaian Diri dan Perilaku Delinkuen pada Remaja di Yogyakarta
}

\author{
Rahmat Aziz \\ Staf Pengajar STAIN Malang Alumnus Program S-2 Psikologi U GM Yogyakarta
}

Abstract

The term emotional quotion is relativety new in psydhology and it is assumed to play significant role in daily life. This reseand f finds out that emotional Intelligence can be used as predictor for personal adjustment and bekcuorial delinquent in adolescent.

\section{Pendahuluan}

Masa remaja merupakan salah satu periode perkembangan manusia yang paling banyak mengalami perubahan. Secara tradisional masa ini biasa disebut dengan masa badai dan tekanan, yaitu suatu masadimana ketegangan emosi meninggi sebagai akibat dari perubahan fisik dan kelenjar. Setiap periode mempunyai masalahnya sendiri-sendiri, namun masalah masa remaja sering menjadi masalah yang sulit diatasi baik oleh anak laki-laki maupun 
anak perempuan. Setidaknya ada dua alasan bagi penyebab kesulitan ini. Pertama, Semasa kanak-kanak, sebagian besar masalah biasa diselesaikan oleh orang tua, sehingga para remaja belum punya pengalaman untuk mengatasi masalahnya sendiri. Kedua, Para remaja merasa dirinya mandiri, sehingga menolak bantuan orang tua, guru, dan orang yang lebihtua lainnya, mereka ingin menyelesaikan miasaiahnya sendiri.

Menurut Darajat (1975) masa remaja merupakan periode perkembangan manusia yang paling banyak mengalami perubahan. Pada masa ini merupakan saat-saat perpindahan darimasa kanak-kanak ke masa dewasa. Berbagai macam perubahan meliputi semua segi kehidupannya seperti perubahan jasmani, pikiman, perasaan dan sosial. Pada umumnya, perubahan tersebut dimulai dari perubahan jasmani yang mencolok pada usia 13 atau 14 tahun. Selanjutnya perubahan tersebut akan diikuti atau disertai dengan adanya perubahan-perubahan lain yang terus berjalan sampai mencapai usia 20 tahun, sehingga bisa dikatakan bahwa masa remaja terjadi antara usia 13 sampai 20 tahun. $^{1}$

Para remaja dalam menghadapi perrnasalahannya bisa digolongkan kedal am dua kelompok. Pertama, mereka yang mampu menyesuaian diri dengan tuntutan dan kebutuhan diri sendiri beserta lingkungannya, mereka adalah remaja yang sukses dalam menjalani kehidupannya. Kedua, mereka yang mengembangkan perilaku delinkuen sebagai bukriketidakmampuannya dalam menyesuaikan terhadap tuntutan diri dan lingkungannya.

Banyak faktor yang mempengaruhi keberhasilan dan kegagalan para remaja. Penelitian yang dilakukan Haditono menemukan bahwa 69,45\% remaja delinkuen memiliki taraf inteligensi di bawah normal. ${ }^{2}$ Norvig menyatakan bahwa yang melakukan kejahatan kesusilaan lebih banyak dilakukan oleh Mentally retarded Persons. Rendahnya tingkat intelegensi menyebabkan remaja tidak mampu melihat dan memperkirakan akibat dari perbuatannya. ${ }^{3}$

Namun menurut Goleman (1996) kecerdasan bila tidak disertai dengan pengolahan emosi yang baik tidaklah akan menghasilkan seseorang sukses dalam hidupnya. Peranan kecerdasan akademik (IQ) hanyalah sekitar $20 \%$ untuk menopang kesuksesan hidup seseorang, sedangkan 80\% lainnya 
ditentukan oleh faktor yang lain, yang diantaranya adalah faktor kecerdasan Emosional. ${ }^{4}$ Pendapat yang sama dikemukakan oleh Stenberg mengatakan bahwa IQ mungkin hanya berperan $4 \%$ dari keberhasilan dunia nyata. ${ }^{5}$ Dengan kata lain, lebih dari $90 \%$ keberhasilan mungkinberhubungan dengan bentuk kecerdasan lain. Pendapat lain dikemukakan oleh Patton yang mengatakan bahwa orang yang mempunyai kecerdasan emosionalnya tinggi ternyata sukses ditempat kerja. ${ }^{6}$

Selanjutnya, perbedaan jenis kelamin antara laki-laki dan perempuan akan menimbulkan perbedaan dalam berperilaku. Menurut Hollingworth (Meichati, 1975) pada umumnya perempuan itu tidak pernah ekstrem bila dibanding dengan laki-laki, sehingga jarang ditemukan wanita yang menonjol dalam beberapa kepribadian, kebanyakan perempuan dalam tarap rata-rata, berbeda dengan laki-laki yang bisa sangat hebat dan sangat cacat. ${ }^{7}$ Selain itu pandangan stereotip dalam masyarakat juga akan mempengaruhi timbulnya perbedaan antara anak laki-laki dan perempuan. Anak laki-laki dipandang lebih tinggi dalam berbagai kemampuan dibandingkan dengan anak perempuan. ${ }^{8}$

Senada dengan pandangan diatas, dikemukakan oleh Kail \& Nelson yang mengatakan bahwa adanya stereotip dalam masyarakat akan berpengaruh dalam memperlakukan seseorang dan juga akan mengakibatkan adanya perbedaan sifat. Laki-laki lebih agresif daripada perempuan, kurang mampu menunda kepuasan, impulsif, dan lebih berani mengambil resiko karena mereka lebih suka bertualang. ${ }^{9}$ Prawitasari dkk, menemukan bahwa ada perbedaan antara laki-laki dan perempuan dalam hal kepribadian. Perempuan mempunyai kecenderungan untuk lebih hangat, emosioanal, sopan, peka, dan mentaati aturan, sedangkan laki-laki cenderung lebih stabil, dominan, dan impulsif. ${ }^{10}$ Penelitian yang dilakukan Farurochman menemukan bahwa laki-laki cendenung lebih ditolerir bila melakukan perilaku seks sebelum nikah. Selain itu ada standar ganda yang membuat laki-laki lebih permisif dalam melakukan perilaku tersebut. ${ }^{11}$

Hasil penelitian dalam hal penyesuaian diri dengan membedakan jenis kelamin ditemukan hasil yang berbeda-beda, ${ }^{12}$ sedangkan penelitian dalam hal perilaku delinkuen menunjukkan hasil yang relatif sama. ${ }^{13}$ 
Berdasarkan landasan teori dan hasil-hasil penelitian terdahulu, dalam penelitian ini diajukan hipotesis:

1. Adda hubungan yang positif antara kecerdasan emosional dengan penyesuaian diri remaja. Semakin tinggi kecerdasan emosional remaja maka semakin tinggi pula penyesuaian dirinya.

2. Ada hubungan yang negatif antara kecerdasan emosional dengan perilaku delinkuen remaja. Semakin tinggi kecerdasan emosional remaja maka semakin rendah perilaku delinkuennya.

3. Ada perbedaan antara remaja laki-laki dan perempuan dalam hal kecerdasan emosional.

4. Ada perbedaan antara remaja laki-laki dan perempuan dalam hal penyesuaian diri. Perempuan cenderung lebih tinggi penyesuaian dirinya dibanding dengan laki-laki.

5. Ada perbedaan antara remaja laki-laki dan perempuan dalam hal berperilaku delinkuen. Laki-laki cenderung lebih tinggi untuk berperilaku delinkuen dibanding dengan perempuan.

\section{Subjek Penelitian}

Subjek penelitian ini berjumlah 230 siswa kelas satu dan dua di SMUN 3, SMUN 5, SMUN 11 (100 Laki-laki dan 130 perempuan) yang dipilih secara cluster random sampling. Proses pengambilan sampel dilakukan dengan cara memilih sebanyak 3 sekolah dari seluruh SMUN yang ada di Yogyakarta secara bertujuan bendasarkan kriteria sekolah yang ditetapkan oleh Kanwil Departemen Pendidikan Dan Kebudayaan yaitu sangat baik, baik, dan cukup, kemudian dari tiap sekolah tersebut diambil dua kelas secara random (kelas 1 dan kelas 2).

\section{Instrumen Penelitian}

Pendekatan yang digunakan untuk mengetahui validitas dalam penelitian ini adalah internal validity yang dalam pelaksanaannya dilakukan dengan dua cara, yaitu: Pertama, analisis butir yang bertujuan untuk mengetahui apakah suatu item itu baik atau tidak. Kedua, analisis faktor yang bertujuan untuk mengetahui bobot faktor terhadap konstruk dan 
mengetahui faktor mana yang memberi sumbangan paling besar. Uji Validitas dilakukan pada 110 siswa di SMUN 9 dan SMUN 10. Semua tehnik analisis dalam penelitian ini menggunakan fasilitas komputer program SPSS for MS WINDOWS.

Kecerdasan Emosional adalah suatu kemampuan untuk mengindra, memahami dan menerapkan kekuatan dan ketajaman emosi sebagai sumber energi, informasi, dan pengaruh. Kemampuan ini dicirikan dengan adanya kemampuan yang bersifat kedalam diri sendiri dan keluar diri. Data ini diperoleh dari skala kecerdasan emosional berdasarkan teori yang dikemukakan oleh Goleman Gardner dan Salovey. ${ }^{14}$

Dari hasil uji validitas ditemukan bahwa 48 item yang diuji tendapat 32 item yang valid dengan koefisien validitas berkisar antara .2085 sampai .5650, sedangkan reliabilitas menunjukkan alfa sebesar $\mu=.8103$. Dari hasil analisis faktor ditemukan bahwa skala ini mampu mengungkap konstruk sebesar $47,7 \%$, sumbangan faktor terhadap konstruk berkisar antara $16,4 \%$ sampai $4,9 \%$.

Peryesuaian diri adalah suatu proses dinamika yang melibatkan responrespon mental dan tingkah laku untuk memenuhi kebutuhan baik dari dalam diri maupun dari luar diri yang tidak bertentangan dengan norma masyarakat, dan berfungsi untuk mengatasi hambatan-hambatan sehingga mencapai keselarasan antara diri dan lingkungan serta diperoleh kebahagiaan hidup. Data ini diperoleh dari skala penyesuaian diri berdasarkan teori yang dikemukakan oleh Schneider. ${ }^{15}$

Dari hasil uji validitas ditemukan bahwa 56 item yang diuji terdapat 44 item yang valid dengan koefisien validitas berkisar antara .2218 sampai .5301 , sedangkan reliabilitas menunjukkan alfa sebesar $\mu=.8773$. Dari hasil analisis faktor ditemukan bahwa skala ini mampu mengungkap konstruk sebesar $45,5 \%$, sumbangan faktor terhadap konstruk berkisar antara $18,3 \%$ sampai $4,2 \%$.

Perilaku delinkuen adalah tinggi rendahnya remaja untuk melakukan tindakan melanggar hukum dan peraturan-peraturan yang berlaku, serta tindakan yang oleh masyarakat dianggap sebagai perbuatan yang tercela. Data 
ini diperoleh dari skala perilaku delinkuen yang mengukur pada aspekaspek perilaku delinkuen berdasarkan teori yang dikemukakan oleh Hurlock $(1973)^{16}$ dan Jensen . ${ }^{17}$

Dari hasil uji validitas ditemukan bahwa 40 item yang diuji terdapat 35 item yang valid dengan koefisien validitas berkisar antara .2632 sampai .6047 , sedangkan reliabilitas menunjukkan alfa sebesar $\mu=.8948$. Dari hasil analisis faktor ditemukan bahwa skala ini mampu mengungkap konstruk sebesar 40,1\%, sumbangan faktor terhadap konstruk berkisar antara 23,7 sampai $4,7 \%$.

Tabel 1. Hasil Uji Validitas Instrumen

\begin{tabular}{|c|c|c|c|c|c|c|c|}
\hline \multirow{2}{*}{$\mathrm{Na}$} & \multirow[b]{2}{*}{ Variabel } & \multicolumn{4}{|c|}{ Analisis Butir } & \multicolumn{2}{|c|}{ Analisis Faktor } \\
\hline & & $\begin{array}{l}\text { Item } \\
\text { Asal } \\
\end{array}$ & $\begin{array}{l}\text { Item } \\
\text { Valid }\end{array}$ & $\begin{array}{c}\text { Koefisien } \\
\text { Valitizs }\end{array}$ & $\begin{array}{c}\text { Reliabilitas } \\
\text { Alfas }\end{array}$ & $\begin{array}{l}\text { Jumlah } \\
\text { Faktor }\end{array}$ & $\begin{array}{c}\text { Jumlah } \\
\text { Sumbangan }\end{array}$ \\
\hline \multirow[t]{2}{*}{1} & Kecerdasan & & & & & & \\
\hline & Emosional & 48 & 36 & $.2085-.5650$ & .8130 & 6 & $47,7 \%$ \\
\hline \multirow[t]{2}{*}{2} & Penyesuaian & & & & & & \\
\hline & Din & 56 & 44 & $.2218-.5301$ & .8773 & 6 & $45,3 \%$ \\
\hline \multirow[t]{2}{*}{3} & Perilaku & & & & & & \\
\hline & Delinkuen & 40 & 33 & 2632-.6047. & .8948 & 4 & $40,1 \%$ \\
\hline
\end{tabular}

\section{Analisis Data Penelitian}

Tehnik analisis data yang digunakan adalah korelasi product moment dari Pearson dan analisis varians, sebelum dilakukan uji analisis terlebih dahulu dilakukan uji prasyarat analisis dengan melakukan uji normalitas sebaran, linearitas bubungan, dan bomogentias varians terhadap ketiga variabel. Hasil uji tersebut menunjukkan bahwa sebarannya normal, hubungannya linear, dan 
variansnya homogen.

\section{Hasil Dan Pembahasan}

Hasil perbandingan mean empiris dengan mean hipotesis pada variabel kecerdasan emosional dan penyesuaian diri menunjukkan hasil yang lebih rendah, artinya kecerdasan emosional dan penyesuaian diri siswa SMUN Kodya Yogyakarta relatif rendah. Berbeda halnya dengan mean empiris variabel perilaku delinkuen yang diperoleh subjek lebih tinggi dibandingkan mean hipotesisnya, artinya perilaku delinkuen siswa SMUN Kodya Yogyakarta relatif tingg.

Tabel 2. Perbandingan mean hipotesis dan mean empiris

\begin{tabular}{|c|l|c|c|}
\hline No & \multicolumn{1}{|c|}{ Nama Variabel } & Mean Hipotesis & Mean Empiris \\
\hline 1. & Kecerdasan Emosional & 96 & 71,19 \\
2. & Penyesuaian Diri & 132 & 85,74 \\
3. & Perilaku Delinkuen & 105 & 147,03 \\
\hline
\end{tabular}

\section{Pembahasan Hipotesis Pertama Dan Kedua}

Hasil analisis data menunjukkan bahwa hipotesis Pertama dan kedua yang menyebutkan adanya hubungan yang positif antara kecerdasan emosional dengan penyesuaian diri dan adanya hubungan negatif antara kecerdasan emosional dengan perilaku delinkuen pada remaja adalah terbukti.

Hasil yang pertama menunjukkan korelasi yang positif antara kecerdasan emosional dengan penyesuaian diri dan bersifat searah, artinya kenaikan skor kecerdasan emosional yang diperoleh subjek akan diikuti dengan kenaikan skor penyesuaian dirinya, kekuatan hubungan antara kedua variabel ini ditunjukkan oleh koefisien korelasi r sebesar .5620.

Hasil yang kedua menunjukkan korelasi yang negatif antara kecerdasan emosional dengan perilaku delinkuen dan bersifat berlawanan, artinya 
kenaikan skor kecerdasan emosional yang diperoleh subjek akan diikuti dengan penurunan skor perilaku delinkuen, kekuntan hubungan antara kedua variabel ini ditunjukkan oleh koefisien korelasi r sebesar -.4728.

Menurut Atkinson dkk koefisien korelasi sebesar $.200 \mathrm{~s} / \mathrm{d} .600$ bisa memiliki nilai praktis dan teoritis dalam membuat prediksi, ${ }^{18}$ sehingga hasil penelitian diatas bisa dikatakan bahwa tinggi rendahnya kecerdasan emosional mampu menjadi salah satu prediktor bagi tinggi rendahnya penyesuaian diri dan perilaku delinkuen.

Hasil penelitian ini mendukung beberapa penelitian sebelumnya yang dilakukan oleh Trinovita yang menemukan bahwa para remaja non-delinkuen memiliki kontrol diri yang relatif tinggi dibanding dengan para remaja delinkuen. Para remaja non-delinkuen mampu mengarahkan energi emosinya ke arah hal-hal yang bermanfaat dan secara sosial dapat diterima. Mereka lebih mampu mengenali, mengerti, mengatur dan mengendalikan emosi dan perilakunya. ${ }^{19}$ Conger \& Gold menemukan bahwa remaja delinkuen kebanyakan memiliki kontrol diri yang rendah dan menunjukkan skor yang tinggi pada pengukuran sifat imfulsif dan pusat kontrol eksternal, serta memiliki skor yang rendah pada perkembangan moral dan hati nurani. ${ }^{20}$

Penelitian Elfida menemukan bahwa kemampuan mengontrol diri mempenganuhi perilaku delinkuen, semakin tinggi kemampuan remaja dalam mengontrol dirinya, maka semakin rendah perilaku delinkuen. ${ }^{21}$ Selanjutnya Hurlock menjelaskan bahwa kontrol diri berkaitan dengan bagaimana ia mengendalikan emosi serta dorongan-dorongan yang berasal dari dalam dirinya. 22

Hasil penelitian inipun mendukung pendapat yang dikemukakan oleh beberapa ahli (Goleman, 1996; Patton; 1998; Cooper \& Sawaf, 1998) yang menyatakan bahwa kecerdasan akademik (IQ) bila tidak disertai dengan pengolahan emosi yang baik tidaklah akan menghasilkan seseorang sukses dalam hidupnya, tapi ada faktor lain yang lebih berperan dalam kesuksesan seseorang, hal ini disebabkan karena kecerdasan akademik (IQ) tidak memberikan kesiapan untuk menghadapi gejolak yang ditimbulkan oleh kesulitan-kesulitan hidup. ${ }^{23}$ 
Dalam hubungannya dengan kemampuan untuk mengenal emosi, sebagai salah satu aspek dari kecerdasan emosional, maka Martani menyatakan bahwa orang yang sehat biasanya mampu mengenal emosi yang dialaminya dan dapat mengekspresikan sesuai dengan aturan yang berlaku di lingkungannya. ${ }^{24}$ Menurut Ekowarni salah satu cara yang bisa digunakan untuk mengembangkan sikap. ini adalah dengan mengembangkan sikap empati yaitu dengan melatih perilaku peduli terhadap orang lain dan mengembangkan kepekaan untuk melihat kesulitan orang lain kemudian berusaha untuk membantunya. ${ }^{25}$

Dalam hubungannya dengan sikap optimis sebagai salah satu aspek dari kecerdasan emosional, Lazanus \& Taylor dari University of California menyebutkan bahwa orang-orang yang optimis cenderung lebih bahagia dalam menikmati hidupnya, selain itu merekapun dapat terhindar dari masalahmasalah mental seperti depresi. Salah satu cara yang bisa digunakan untuk mengembangkan sikap optimis adalah dengan membiasakan berpikir positif yaitu suatu cara pandang terhadap suatu masalah dari sisi yang positip dan mengharapkan hasil yang terbaik. ${ }^{26}$

Tabel 3. Hasil Uji Korelasi dengan Product-moment

\begin{tabular}{|l|c|c|}
\hline Variabel Yang dikorelasikan & Nilai r & Nilai P \\
\hline Kecerdasan Emosional \& Penyesuaian Diri & .5620 & .0000 \\
\hline $\begin{array}{l}\text { Kecerdasan Emosional \& Kec. Berperilaku } \\
\text { Delinkuen }\end{array}$ & -.4728 & .0000 \\
\hline
\end{tabular}

\section{Pembahasan Hipotesis Ketiga, Keempat Dan Kelima}

Hasil analisis varians yang menguji mengenai perbedaan laki-laki dan perempuan dalam hal kecerdasan emosional, penyesuaian diri, dan perilaku delinkuen pada remaja menunjukkan bahwa nilai $F$ yang diperoleh tidak signifikan, sehingga bisa disimpulkan bahwa ketiga hipotesis yang menyatakan adanya perbedaan pada ketiga variabel dinyatakan ditolak, baik 
pada taraf signifikansi 1\% maupun pada taraf signifikansi 5\%. Bahkan hasil pengujian pada hipotesis kelima menunjukkan bahwa perempuan cenderung lebih tinggi untuk berperilaku delinkuen bila dibanding dengan laki-laki pada taraf signifikansi 5\%, dengan perbandingan mean 144:148.

Secara statistik, tidak terbuktinya hipotesis ini mungkin disebabkan oleh adanya kesalahan sampel (sampling error) karena sampelnya merupakan gabungan dari beberapa kelas sehingga bentuknya menjadi heterogen. $\mathrm{Hal}$ ini bisa dilihat dari standar error yang ditunjukkan dalam hasil analisis sangat besar.

Hasil analisis pada hipotesis ketiga menunjukkan $\mathrm{F}=1.0469$ dan $\mathrm{P}=.3073$. Hasil ini sejalan dengan penelitian mengenai emosi, yang pernah dilakukan oleh Prawitasari menemukan bahwa tidak adanya perbedaan antara laki-laki dan perempuan dalam hal mengekspresikan emosi dasar seperti rasa rasa jijik, marah, terkejut, dan lain sebagainya, kecuali dalam mengekspresikan rasa malu. ${ }^{27}$ Selain itu mungkin disebabkan karena pengalaman subjek termasuk didalamnya adalah pendidikan formal adalah relatif sama, karena menurut Goleman pada dasarnya kecerdasan emosional lebih banyak dipengaruhi oleh faktor lingkungan dan pengalaman seseorang bila dibanding dengan faktor bawaan. ${ }^{28}$

Hasil analisis pada hipotesis keempat menunjukkan nilai $\mathrm{F}=.6397$ dan $\mathrm{P}=.4247$. Hasil ini memperkuat hasil penelitian yang dilakukan oleh Tidjan \& Kusumastuti yang menemukan bahwa tidak adanya perbedaan laki-laki dan perempuan dalam hal penyesuaian diri. ${ }^{29}$

Faktor lain yang mungkin berpengaruh padatidak terbuktinya hipotesis ini karena meningkatnya kesempatan bagi perempuan untuk berperan sama seperti yang dicapai oleh laki-laki dalam berbagai macam aktivitas yang ada dalam masyarakat, terutama di pusat-pusat kota dan pada kalangan menengah kelas atas. Menurut Thornburg Remaja-remaja perempuan yang tumbuh dalam kondisi semacam ini, akan mengidentifikasikan diri dengan peran ibunya, dimana para ibu percaya bahwa dirinya adalah sederajat dengan laki-laki dan mampu melakukan sesuatu yang biasa dilakukan oleh laki-laki. ${ }^{30}$

Ada beberapa alasan yang menyebabkan mengapa tidak terdapat 
perbedaan antara laki-laki dan perempuan dalam hal kecerdasan emosional dan penyesuaian diri, yaitu:

1. Pada dasarnya remaja laki-laki dan perempuan mempunyai kebutuhan yang sama dalam mengaktualisasikan diri, sehingga mereka mempunyai peluang yang sama untuk tumbuh dan berkembang.

2. Tuntutan dan kondisi lingkungan sekolah dimana para remaja tinggal relatif sama, sehingga mereka berusaha memenuhi tuntutan tersebut dengan cara yang sama pula.

Hasil penelitian pada hipotesis kelima menunjukkan $\mathrm{F}=6.4215$ dan $\mathrm{P}=.0119$, hal ini berarti hipotesis kelima yang menyebutkan adanya perbedaan antara laki-laki dengan perempuan dalam hal perilaku delinkuen adalah tidak terbukti, bahkan dari hasil yang diperoleh ditemukan bukti bahwa perempuan cenderung lebih tinggi kemungkinannya untuk berperilaku delinkuen bila dibanding dengan remaja laki-laki pada taraf signifikansi $5 \%$.

Hasil penelitian ini sangat menarik untuk dikaji lebih lanjut karena kebanyakan hasil yang diperoleh terhadap tema yang sama sering ditemukan laki-laki lebih tinggi kemungkinannya untuk berperilaku delinkuen bila dibanding dengan perempuan ${ }^{31}$ atau hasil yang lain ditemukan tidak adanya perbedaan antara laki-laki dengan perempuan dalam perilaku delinkuen. ${ }^{32}$

Tapi walaupun demikian, hasil penelitian ini menjadi menarik untuk dikaji lebih lanjut sehubungan dengan adanya pendapat yang dikemukakan oleh Conger yang mengatakan bahwa walaupun ditemukan adanya perbedaan laki-lakicenderung lebih tinggi untuk berperilaku delinkuen bila dibanding dengan perempuan tapi bukti terakhir menunjukkan perbedaannya semakin mengecil. ${ }^{33}$

Faktor yang mungkin menjadi alasan tidak terbuktinya hipotesis ini adalah karena adanya kesempatan yang sama dansemakin luas bagi perempuan untuk berperilaku sama dengan laki-laki. ${ }^{34}$ Keadaan seperti ini dirasakan sebagai suatu kebebasan bagi perempuan untuk mengekspresikan seluruh apa yang diinginkan dan dirasakannya. Selain itu, faktor yang ikut menentukan bagi terciptanya kondisi seperti ini juga karena kontrol masyarakat yang semakin longgar terhadap perilaku delinkuen yang dilakukan oleh perempuan. 
Tabel 5. Hasil Uji Analisis Varians

\begin{tabular}{|c|c|c|c|c|}
\hline Sumber Varians & $\begin{array}{l}\text { Nilai F } \\
\text { Rasio }\end{array}$ & $\begin{array}{l}\text { Nilai F } \\
\text { Error }\end{array}$ & $\begin{array}{c}\text { Putudan } \\
\text { Mean }\end{array}$ & $\begin{array}{l}\text { Standard } \\
\text { Error }\end{array}$ \\
\hline KE & 1.0469 & .3073 & $72: 70$ & .7484 \\
\hline PD & .6397 & .4247 & $86: 85$ & 1.0090 \\
\hline KBD & 6.4215 & .0119 & $144: 148$ & .8596 \\
\hline
\end{tabular}

\section{Penutup}

Berdasarkan uraian diatas dapat disimpulkan bahwa: Pertama, kecendasan emosional dan penyesuaian diri pada remaja di Kodya Yogyakarta relatif rendah, sedang kecenderunganny untuk berperilaku delinkuen adalah relatif tinggi. Kedua, terdapat hubungan yang positif antara kecerdasan emosional dengan penyesuaian diri dan hubungan yang negatif dengan perilaku delinkuen. Ketiga, tidak terdapat perbedann yangsignifikan antara remaja laki-laki dan perempuan dalam hal kecerdasan emosional dan penyesuaian diri, tapi terdapat perbedaan dalam hal perilaku delinkuen, perempuan cenderung lebih tinggi untuk berperiaku delinkuen bil a dibanding dengan laki-laki.

Dari sini saran yang dapat diberikan adalah sebagai berikut: kepada para orangtua dan guru, hendaklah lebih memahami keadaan para remaja dengan segala karakteristiknya, karena pemahaman yang tepat terhadap mereka dapat membantu mereka dalam mengatasi persoalan-persoalan hidupnya Kepada para remaja, hendaklah beruseha untuk lebih memahami dan meningkatkan kecerdasan emosional, karena dari hasil penelitian yang diperoleh ternyata kecerdasan emosional mampu dijadikan sebagai predikcor bagi kemampuan untuk penyesuaian diri dan menekan kecenderungan untuk berperilaku delinkuen Kepada peneliti selanjutmka, hendaknya menggunakan tehnik pemilihan sampel yang lebih tepat sehingga kemungkinan terjadi sampling error semakin kecil selain itu dalam memilih sekolah perlu melibatkan sekolah swasta agar generalisasinya semakin luas. Dalam hal instrumen 
penelitian peneliti menyarankan untuk diperbaiki sehingga ditemukan instrumen yang baku.

\section{Notes:}

1. Zakiyah Darajat, Kesehatan Jinea Dalam Keluarga, Sekolah, Dan Masjarakat, (Jakarta. Bulan Bintang, 1977).

2. Haditono, dalam Monks, E.J. Knoers, A.M.P., \& Haditono, S.R., Psikologi Perkembangan, (Yogyakarta: Gadjah Mada University Press, 1982).

3 Norvig, dalam Simanjuntak, B., Latar Belakang Kenakalan Anak, Etiology Juvenile Delinqueno, (Bandung: Alumni, 1984).

4. Goleman, D., Emotional Intelligence (Alih bahasa Hermaya) (Jakarta: Gramedia,1995).

5. Cooper,R.K, \& Sawaf, A, EvecuiveEQ, Keccrdasen Enosional Dalon Kepenimpinen Dan Organisasi, (Alib babasa Widodo)Jakarta: Gramedia, 1998.

6. Patton, Emotional Intelligence Di Tempat Kerja, (Alih Bahasa Dahlan) Jakarta Pustaka Delapratasa, 1998.

7. Hollingworth, Meichati, S, "Penelitian Tentang Tanggapan Remaja Mengenal Diridan Kehidupan", Laporan Penelitian, Yogyakerta: Lembaga Penelitian UGM, 1975).

8. NMulder, Pribadi Dan Masyarakat Di Jarea, (Jakarta: Sinar Harapan, 1985).

9. Kail,R.V., \& Nelson, N.W., 1992, Development Pyobology, Englewoods Clifs, (New Jersey: Prentice Hall inc, 1993).

10. Prawitasari dkk, 1985; 1993, "Apakah Wanita Lebih Peka Daripada Pria Dalam Mengartikan Emosi Dasar Manusia?”, Jumal Psikologi, No.1, (Yogyakara' Fakultas Psikologi Gadjah Mada, 1993), 14-22.

11. Fanurochman, "Sikap dan Perilaku Seksual Remaja di Bali", Jumal Psikologi, No.1, (Yogyakarta: Fakultas Psikologi Universitas Gadjah Mada, 1992), 12-17.

12. Tidjan, "Perbedaan Penyesuaian Diri di Sekolah ditinjau dari Sikap Terhadap Layanan Bimbingan dan Konseling di Sekolah, Jenis Kelamin, dan Tingkat Kelas Para Siswa SMAN 9 Yogyakarta", Tesis, (Yogyakarta: Program Pascasarjana Psikologi Universitas Gadjah Mada,1989) Purwati dan Partosuwido, dalam Purwati, "Hubungan Antara Pola Asuh Orangtua Dengan Penyesuaian Diri Di Kodya Magelang", Tesis, (Yogyakarta: Program Pascasarjana UGM, 1993).

13. Conger, J.J., Adolescence and Youth, (New York: Harper \& Row, Publishers, 1977). Elfida, D., Hubungan Antara Kemompuen Mengontrol Dividan Kecendenongan Betperilabu Delinkuen",Skripsi, (Yogyakarta. Fakultas Psikologi Universitas Gadjah Mada, 1995). Kumiawan, I.N., "Orientasi Religius dan Kecenderungan Berperilabu 
Delinkuen", Skripsi, (Yogyakarta: Fakultas Psikologi UGM, 1997).

14. Goleman Gardner dan Salovey, Emotional Intelligence (Alih bahasa Hermaya), (Jakarta: Gramedia, 1996).

15. Schneider, A.A., Ptrsonal Adjustment and Mental Health, (New York: Holt, Rinehart and Winston. 1964).

16. Hurlock, E., Child Development, (Tokyo: Mc Graw Hill Kogakusha, Ltd. 1973).

17. Jensen (dalam Sarwono, 1994)

18. Atkinson, R.L., Atkinson, R.C., \& Hilgard, E.R, Introduction to Pyychology, (New York: Harcourt Brace Jovanovich Inc, 1979)

19. Trinovita, dalam Mulyono, Y.B., 1996, Pendekatan Analisis Kendealan Remaja dan Penanggulangannya, (Yogyakara. Kanisius, 1992).

20. Fuhrmann, B.S., Adolescence, Adolesent, (1llinois: Brown Higher Education, 1990).

21. Elfida, D., Loc.cit.

22. Hurlock, E., loc.cit.

23. Goleman, D., loc.cit Patton, P., Emotional Intelligence Di Tempat Kerja, (Alih Bahasa Dablan), Oakarta: Pustaka Delapratasa. 1998). Cooper, R.K., E Saweaf, A., Executive EQ, Kecerdasan Emosional Dalam Kepemimpinan Dan Organisasi, (Alib bahasa Widodo), Oakarta: Gramedia. 1998).

24. Martani, W., MengenaliEmosi Melalui Rangsang Gambardan Suara, (Penelitian), (Yogyakarta: Fakultas Psikologi Universitas Gadjah Mada, 1996)

25. Ekowarni, E., "Mengembangkan Kecerdasan Emosional Dalam Keluarga”, Makalah, (Yogyakarta: Wisma Kagama, 1997).

26. Lazanus \& Taylor dari University of California, dalam Peale, N.V., 1992, The Power of Positive Thinking, Englewoods Clifs, (New Jessey: Prentice Hall inc, 1953).

27. Prawitasari, J.E., loc.cit., 14-22.

28. Goleman, D., loccit

29. Tidjan \& Kusumasnuti, loc.cit.

30. Thomburg, H.D., Development in Adolescence, (California: Brook/cole Publishing Company, 1982).

31. Elfida, D., loc.cit.

32. Kumiawan, I.N., loccit

33. Conger, J.J., 1977, loc.cit.

34. Thomburg, H.D., loccit. 


\section{Bibliography}

Atkinson, R.L., Atkinson, R.C., \& Hilgard, E.R., 1979, Introduction to Psychology,

New York: Harcourt Brace Jovanovich Inc.

Cole, L., 1963, Psychology of Adolescence, Psychological Development in a Changing World,

New York: Holt, Rinehart and Winston Inc.

Conger, J.J., 1977, Adolescence and Youth, New York: Harper \& Row, Publishers.

Cooper, R.K., \& Sawaf, A., 1998, Executive EQ, Kecerdasan Emosional Dalam

Kepemimpinan Dan Organisasi, (Alih bahasa Widodo) Jakarta: Gramedia.

Darajat, Z., 1977, Kesehatan Jiwa Dalam Keluarga, Sekolah, Dan Masyarakat, Jakarta:

Bulan Bintang.

Ekowarni, E., 1997, "Mengembangkan Kecerdasan Emosional Dalam Keluarga”, Makalah, Yogyakarta: Wisma Kagama.

Elfida, D., 1995, "Hubungan Antara Kemampuan Mengontrol Diri dan Kecenderungan Berperilaku Delinkuen”, Skripsi, Yogyakarta: Fakultas Psikologi Universitas Gadjah Mada.

Faturuchman, 1992, "Sikap dan Ptrilater Seksual Remaja di Bali", Jurmal Psikologi, No.1, 12-17, Yogyakarta: Fakultas Psikologi Universitas Gadjah Mada.

Fuhrmann, B.S., 1990, Adolescrace, Adolesent, Illinois: Broen Higher Education

Goleman, D., 1995, Emotional Intelligence (Alih bahasa Hermaya) Jakarta: Gramedia.

Hurlock, E., 1973, Child Development, Tokyo: Mc Graw Hill Kogakusha, Ltd.

Kail, R.V., \& Nelson, N.W., 1993, Development Psychology, Englewioods Clifs, New Jersey: Prentice Hall, inc.

Kurniawan, I.N., 1997, "Orientasi Religius dan Kecenderungan Berperilaku Delinkuen", Skripsi, Yogyakara: Fakultas Psikologi UGM.

Marani, W., 1996, Mengenali Emosi Melalui Rangsang Gambardan Suara, (Penelitian) Yogyakarta: Fakultas Psikologi Universitas Gadjah Mada.

Meichati, S, 1975, Penelitian Tentang Tanggapan Remaja Mengenal Diridan Kehidupan, (Laporan Penelitian) Yogyakarta: Iembaga Penelitian UGM.

Mulder, N., 1985, Pribadi Dan Masyarakat Di Jawa, Jakarta: Sinar Harapan.

Mulyono, Y.B., 1992, Pendekatan Analisis Kenakalan Remaja dan Penangzulangannya, Yogyakarta: Kanisius.

Patton, P., 1998, Emotional Intelligence Di Tempat Kerja, (Alih Bahasa Dahlan) Jakarta: Pustaka Delapratasa.

Peale, N.V., 1953, The Power of Positive Thinking, Englewoods Clifs, New Jersey: 
Prentice Hall, inc.

Prawiitasari, J.E., 1993, "Apakah Wanita Lebih Peka Daripada Pria Dalam Mengarrikan

- Emosi Dasar Manusia ?”, Jurnal Psikologi, No.1, 14-22, Yogyakarta: Fakultas Psikologi Gadjah Mada.

—_, \& Kahn, M.W., 1985, "Personality differences and sex similarities in American and Indonesian College Student", The Journal of Social Psychology, 124, 703-708.

Purwati, 1993, "Hubungan Antara Pola Asuh Orangtua Dengan PenyesuaianDiri Di Kodya Magelang", Tesis, Yogyakarta: Program Pascasarjana UGM.

Schneider, A.A., 1964, Rersonal Adjustment and Mental Health, New York: Holt, Rinehart and Winston.

Simanjuntak, B., 1984, Latar Belakang Kenakalan Anak, Etiology Juvenile Delinguency, Bandung: Alumni.

Thomburg, H.D., 1982, Development in Adolescence, Califomia: Brook/cole Publishing Company.

Tidjan, 1989, "Perbedaan Penyesuaian Diri di Sekolah ditinjau dari Sikap Terhadap Layanan Bimbingan dan Konseling di Sekolah, Jenis Kelamin, dan Tingkat Kelas Para Siswa SMAN 9 Yogyakarta", Tesis, Yogyakarta: Program Pascasarjana Psikologi Universitas Gadjah Mada. 